\title{
Conflicto de poderes en torno a las imágenes y alhajas sagradas de los conventos suprimidos en la naciente República de Colombia*
}

Power conflicts around the images and sacred elements
from suppressed convents in the early Republic of Colombia

Roger PITA PICO

Academia Colombiana de Historia

rogpitc@hotmail.com

\begin{abstract}
The purpose of this article is to analyze the problems that arose around the sacred elements of the convents suppressed by order of the nascent government of the Republic of Colombia and their sale in order to fund public schools. A series of conflicts arose between the legitimate power that the clergy asserted over their sacred elements, the government's desire to obtain resources for its ambitious educational projects and, on the other hand, the faithful who presented their rightful claim to maintain their devotion to their sacred images.
\end{abstract}

Keywords: sacred elements, convents, Catholic Church, schools, Colombia, 19th century.
Resumen: El propósito de este artículo consiste en analizar la problemática suscitada en torno a las alhajas de los conventos suprimidos por orden del naciente gobierno de la República de Colombia y su destinación para la financiación de los colegios públicos. Se abrió paso entonces a una serie de conflictos entre el poder legítimo que alegaba el estamento eclesiástico sobre sus elementos sagrados, el afán del gobierno por conseguir recursos para su ambicioso proyecto educativo y, por otro lado, la feligresía que clamaba su justo derecho a mantener su devoción hacia sus imágenes sagradas.

Palabras clave: imágenes sagradas, conventos, Iglesia católica, colegios, Colombia, siglo XIX.

* El presente artículo hace parte de un proyecto de investigación que de manera independiente adelanta el autor sobre Educación, Estado e Iglesia en Colombia en los primeros años de la República: los dilemas y entresijos del proceso de construcción nacional. 


\section{INTRODUCCIÓN}

Durante el periodo colonial, la Iglesia ocupaba un lugar preponderante en la sociedad de la América hispánica. Ampliamente reconocido era su poder económico, su fortaleza institucional, su influencia moral, su aceptación social y su presencia en los rincones más recónditos de la Nueva Granada ${ }^{1}$. Desde aquellos tiempos del antiguo régimen, los neogranadinos mostraron una profunda religiosidad popular reflejada en la devoción a sus imágenes sagradas, en los actos litúrgicos, en las fiestas religiosas y en las romerías. Buena parte de estas expresiones piadosas fueron heredadas de España, adalid del catolicismo en el mundo ${ }^{2}$, $\mathrm{y}$ otras fueron fruto del sincretismo con creencias religiosas indígenas y africanas.

En las guerras de Independencia (1810-1822), fase en la cual patriotas y españoles entablaron una larga lucha por el poder político, varios religiosos fueron perseguidos por sus inclinaciones políticas mientras que las instalaciones y propiedades de los conventos e iglesias padecieron graves perjuicios por cuenta del intenso conflicto político y militar. Dentro de estas pertenencias, sin lugar a dudas los ornamentos y las alhajas fueron las más apetecidas por la facilidad para cargarlas y comercializarlas en razón a su apreciable valor por contener oro, plata y otras piedras preciosas. Con bastante frecuencia, estos elementos sagrados resultaban afectados por las órdenes de confiscación, el despojo violento y la destrucción en medio de la tensión, el odio y la venganza derivada de estas guerras.

Hacia 1819, tras el triunfo alcanzado en la batalla de Boyacá, los republicanos emprenden la recuperación del poder político y la expulsión definitiva de los españoles y, con ello, disminuye el ambiente de zozobra y convulsión. Mientras la Iglesia católica mantenía su poder como grupo dominante, el Estado republicano emerge en medio de un déficit de recursos y una debilidad institucional ${ }^{3}$.

Las alhajas y ornamentos que sobrevivieron a este periodo de guerra seguían siendo pretendidos por su valor económico y espiritual y, paradójicamente, también fueron vulnerables a las decisiones políticas asumidas por el naciente gobierno libre ${ }^{4}$. Por los azares del destino, en estos años la vida de los colegios y la de los

1 Fernán GONZÁLEZ, Iglesia y Estado en Colombia durante el siglo XIX (1820-1860), Bogotá, 1985, pp. 17-18.

2 Javier OCAMPO LÓPEZ, Las fiestas y el folclor en Colombia, Bogotá, 2006, p. 40.

3 Jorge Villegas ARANGo, Colombia: enfrentamientos Iglesia-Estado 1819-1887, Medellín, 1977, p. 1.

4 Esta no fue la única medida de este tipo, pues ese mismo año el Congreso de la República adjudicó al fisco todos los bienes y rentas de la Inquisición. Juan Pablo RESTREPO, La Iglesia y el Estado en Colombia, Bogotá, 1987, t. I, p. 97. 
conventos terminaron entrecruzadas. La crisis padecida por estas congregaciones religiosas fue retomada por el gobierno nacional como una oportunidad propicia para recaudar fondos dirigidos a promover la educación pública que era una de las grandes banderas del proyecto republicano bajo el liderazgo del vicepresidente Francisco de Paula Santander 5 .

Desde sus inicios, el proyecto republicano en materia educativa proclamó la necesidad inaplazable de erradicar muchos de los anquilosados postulados del modelo colonial, lo cual implicaba hacer énfasis en la educación práctica, útil y racional con un espíritu liberal y laicista en lugar de la tradicional enseñanza monacal. Para avanzar en esa meta, el vicepresidente Santander promovió en los colegios la difusión de la doctrina utilitarista del liberal inglés Jeremías Bentham, ideas que provocaron la reacción de la Iglesia y de algunos sectores conservadores $^{6}$.

El nivel de educación secundaria, por su misma complejidad administrativa y curricular, demandaba crecidos gastos de sostenimiento ${ }^{7}$. Pese al apoyo del erario central y a las iniciativas locales y comunitarias, fueron innumerables las dificultades financieras experimentadas en el proceso de implementación de estas instituciones educativas pues había que conseguir recursos para la adecuación de la sede, la dotación y el pago de maestros, entre otros gastos.

Según el decreto expedido el 20 de junio de 1821, los fondos para los colegios o casas de educación se componían de: las capellanías vacantes, los sobrantes de las rentas de propios de los cabildos, las donaciones de vecinos pudientes y otros aportes que se pudieran gestionar ${ }^{8}$. La tendencia anticlerical adquirió mayor impulso en el Congreso de la República y, tras un resultado de 32 votos a favor y 10 en contra ${ }^{9}$, el 28 de julio de este mismo año fue aprobada otra ley que significó una nueva alternativa de financiación para los colegios pero, a la vez,

5 Para el nuevo gobierno republicano, la instrucción pública era la base del progreso, del bienestar, de la felicidad y de la formación de ciudadanos libres y con capacidad para asimilar sus derechos y deberes en sociedad. Luis Horacio LÓPEZ DOMÍNGUEZ, Las grandes escuelas públicas de educación primaria y secundaria, en Fernando CEPEDA UlloA (ed.), Fortalezas de Colombia, Bogotá, 2007, t. II, p. 152.

6 Marta Helena LóPez Rodríguez y Patricia Pinto Quintero, La Iglesia católica y el Estado en Colombia, Bogotá, 1991, pp. 201-203.

7 Frank SAFFORD, El ideal de lo práctico. El desafío de formar una elite técnica y empresarial en Colombia, Bogotá, 1989, p. 79.

8 Luis Horacio López Domínguez, Obra educativa de Santander 1819-1826, Bogotá, 1990, t. I, p. 44.

9 Roberto Cortázar y Luis Augusto Cuervo, Congreso de Cúcuta. Libro de Actas, Bogotá, pp. 313 382. 
fue un duro revés para las ya debilitadas órdenes religiosas. Esta ley ordenó la supresión de los conventos que contaran con menos de ocho religiosos y destinó preferentemente sus bienes y fondos para la dotación y subsistencia de los colegios o casas de educación ${ }^{10}$.

El proceso de decadencia de los conventos en Colombia venía evidenciándose desde las postrimerías del periodo colonial debido al crítico estado financiero generado por la reducción del número de capellanías que eran la base de su sobrevivencia económica. Se registró además una merma en el número de integrantes de estas congregaciones ${ }^{11}$ en razón a que eran muy contados los jóvenes que habían ingresado a la vida religiosa ${ }^{12}$. No pocos habían fallecido, muchos estaban enfermos o en avanzada edad y otros se hallaban exclaustra$\operatorname{dos}^{13}$ o habían ingresado al clero secular. La pobreza generalizada, la tensión político-militar y las amenazas habían afectado ostensiblemente la vida conventual ${ }^{14}$. A esto había que agregarle las divisiones internas, la indisciplina y la pérdida del valor simbólico de estas instituciones, pues las élites criollas locales ya no veían muchas ventajas en enviar a sus hijas e hijos a la vida conventual. Esta situación de decadencia fue aprovechada por algunos sectores sociales y políticos anticlericales para emprender una campaña difamatoria. Vale anotar además que algunos frailes no vacilaron en apoyar la política de supresión de conventos ${ }^{15}$.

El vicepresidente Santander había dispuesto que las diligencias de supresión de conventos debían realizarse en un mismo día, el 19 de octubre, para evitar los fraudes y la ocultación premeditada de bienes ${ }^{16}$. No obstante, en la práctica ese era un mandato difícil de cumplir debido al complejo estado físico y financiero de

10 Gaceta de la ciudad de Bogotá capital de la República de Colombia, n. ${ }^{\circ}$ 125, Bogotá, Imprenta del Estado por Nicomedes Lora, 1821, p. 403.

11 Según el censo de población adelantado en 1825, el número de miembros del estamento eclesiástico se había reducido en una séptima parte en comparación con las cifras registradas antes de las guerras de Independencia. David Bushnell, El Régimen de Santander en la Gran Colombia, Bogotá, 1985, p. 242.

12 Bastante inconformidad generó en el estamento eclesiástico la medida adoptada por el gobierno de limitar a 25 años la edad mínima de ingreso a la vida religiosa. Representación de los Prelados de los Conventos de Bogotá al Soberano Congreso, Bogotá, 1827, pp. 1-4.

13 Marta Helena López Rodríguez y Patricia PINTO QuiNTERo, La Iglesia católica..., op. cit., p. 192.

14 Luis Carlos Mantilla, Los Franciscanos en Colombia, Bogotá, 2000, t. III, vol. I, p. 641.

15 William Elvis Plata QUEZADA, Declive de un convento of fin de un modelo de relaciones Iglesia, política y sociedad en Nueva Granada, 1820-1863, en Historelo, 12 (2014), pp. 69-92.

16 Archivo General de la Nación (AGN), Bogotá-Colombia. Sección República, Fondo Negocios Eclesiásticos, t. 5 , f. 225 r. 
estas instituciones religiosas. $\mathrm{Al}$ parecer, los temores que inquietaban al general Santander resultaron tener cierto asidero pues algunas órdenes se apresuraron a vender sus más valiosos tesoros ante las amenazas de expropiación ${ }^{17}$. Ejemplo de ello fue el guardián del convento de San Francisco de la ciudad de Pamplona, quien procedió a esconder las alhajas más preciosas: una lámpara de plata de más de 60 onzas, algunos ornamentos, un cáliz y unas vinajeras. El hecho fue corroborado por varios testigos y fue denunciado por el cabildo y el cura parroquial ante el gobernador de la provincia ${ }^{18}$.

Nuevas disposiciones fueron prescritas para mejorar la administración de los bienes y rentas de los conventos suprimidos. En respuesta a una consulta elevada el 10 de diciembre al Consejo de Gobierno, se decidió que las alhajas de oro, plata y otras que no fueran vasos sagrados, podían venderse para la educación pública, conforme a lo estipulado en la ley del 28 de julio. Entre tanto, las otras alhajas debían dejarse en los templos, entregándose debidamente inventariadas a los respectivos párrocos ${ }^{19}$.

En desarrollo a lo dispuesto por la ley, para 1822 se habían cerrado un total de 22 conventos. El 26 de septiembre de este año, se confirieron facultades especiales a los rectores de los colegios para que administraran los bienes y alhajas de dichos conventos ${ }^{20}$. Sin duda, el gobierno republicano fue muy hábil en esta política de supresión de conventos pues colocaba como propósito la educación pública y el progreso de la nación, dos derroteros loables que en principio daban muy poco campo a los cuestionamientos y a las críticas. Con ello, se hacía énfasis en el carácter prioritario del beneficio público por encima de cualquier interés privado o particular. En el fondo, esta medida respondía también a los intereses del Estado, del clero secular y de la oligarquía criolla para liberar tierras que por aquella época estaban muy escasas ${ }^{21}$.

Pero, por otro lado, esta serie de medidas restrictivas provocaron bastante oposición en la feligresía y, particularmente, en el estamento eclesiástico que consideraba esas decisiones como una franca intromisión del gobierno republicano que hasta ese momento no se había acogido al Patronato ni tampoco había elevado consultas a la Santa Sede para disponer de aquellos bienes pese a que el

\footnotetext{
17 William Elvis Plata QueZada, Declive de un convento..., op. cit., p. 86.

18 AGN, Sección República, Fondo Negocios Eclesiásticos, t. 5, ff. 231r-232v.

19 Acuerdos del Consejo de Gobierno de la República de Colombia, 1821-1824, Bogotá, 1988, t. I, pp. 9-10.

20 Gaceta de Colombia, n. ${ }^{\circ}$ 52, Bogotá, 1822, p. 1; José María de Mier, La Gran Colombia, Bogotá, 1983, t. 1, p. 132.

21 William Elvis Plata QueZada, Declive de un convento..., op. cit., p. 88.
} 
gobernador del Arzobispado había instado al poder ejecutivo a establecer relaciones con la Silla apostólica ${ }^{22}$.

En el balance de su informe de gestión presentado al Congreso de la República en abril de 1823, el secretario del Interior José Manuel Restrepo reconoció que la ley de supresión de conventos seguía suscitando innumerables dudas en todo el territorio nacional. El mismo gobierno central todavía no estaba seguro de si los ornamentos y vasos sagrados debían incluirse en los bienes aplicados a los colegios y casas de educación o si había que asegurarles otro destino. Por lo menos, se era consciente de que la venta de estas alhajas en remate no sería bien recibida por los pueblos pero, por otro lado, se advirtió con preocupación el hecho de que algunos de estos elementos sagrados podían perderse o deteriorarse si se guardaban indefinidamente. Pensaba entonces el ministro Restrepo que era conveniente que los ornamentos y alhajas que no fueran imprescindibles para los colegios fueran repartidos en las iglesias pobres de las parroquias inmediatas a los conventos suprimidos ${ }^{23}$.

La ley del 7 de abril de 1826 ratificó la orden de supresión de los conventos menores dispuesta en la ley del 28 de julio de 1821 y, adicionalmente, fue ampliada la medida a aquellos claustros regulares que no contaran con los fondos indispensables para la subsistencia de sus miembros. Se ordenó además que los edificios y bienes muebles de los conventos menores suprimidos que no estuviesen aplicados ni pudiesen conservarse o, que no fueran adaptables al servicio de los colegios, podían ser enajenados al contado o a censo. Los demás bienes raíces serían adjudicados a los colegios ya establecidos o a los que se fundaran en lo sucesivo ${ }^{24}$.

Un nuevo giro dio este tema de las alhajas con el decreto firmado el 10 de julio de 1828 por el presidente Simón Bolívar, mediante el cual se restablecieron los conventos suprimidos pero, los que ya habían sido convertidos en centros de educación pública, debían continuar cumpliendo esa misión. Los muebles y alhajas de iglesias que no se hubiesen enajenado debían ser entregados a los superiores de las órdenes regulares ${ }^{25}$. Al vaivén de las disputas políticas entre la tendencia santanderista y la bolivariana ${ }^{26}$, a principios de 1832 se expidió un

22 José Manuel Groot, Historia eclesiástica y civil de Nueva Granada, Bogotá, 1953, t. IV, p. 261.

23 José Manuel RestrePO, Memoria que el secretario de Estado y del despacho del Interior presentó al Congreso de Colombia sobre los negocios de su Departamento, Bogotá, 1823, p. 26.

24 El Constitucional, n. ${ }^{\circ}$ 86, Bogotá, 1826, p. 2; Andrés MESANZA (fray), Apuntes y documentos sobre la Orden Dominicana en Colombia, Caracas, 1936, pp. 136-137.

25 Gaceta de Colombia, n. ${ }^{\circ} 362$, julio 24 de 1828, p. 1.

26 Desde finales de la década del 20 se acentuaron las diferencias políticas entre los seguidores de las ideas progresistas pregonadas por el vicepresidente Francisco de Paula Santander y los partidarios de la tendencia conservadora liderada por el presidente Simón Bolívar. 
nuevo decreto anulando lo dictaminado por Bolívar en 1828. Por consiguiente, recobraron vigencia las leyes de 1821 y 1826 que estipulaban la supresión de conventos ${ }^{27}$.

Vista la compleja dinámica de estos antecedentes, el propósito de este artículo consiste en analizar el azaroso destino de las alhajas de los conventos suprimidos por orden del naciente gobierno republicano en el área central y nororiental del territorio de lo que actualmente es la República de Colombia que, para el tiempo estudiado correspondía a Cundinamarca, uno de los tres departamentos que integraban la Gran Colombia.

Se abrió paso entonces a una serie de conflictos entre el poder legítimo que alegaba el estamento eclesiástico sobre sus elementos sagrados, el afán del Gobierno por conseguir recursos frescos para su ambicioso proyecto educativo y, por otro lado, la feligresía que clamaba su justo derecho a que se mantuviera intacta su devoción hacia sus imágenes sagradas. Este trabajo necesariamente remite a reflexionar sobre las relaciones entre Iglesia y Estado en Colombia ${ }^{28}$ al tiempo que se inscribe también desde la óptica de la «nueva historia de la educación», corriente historiográfica que permite profundizar sobre el ámbito económico del sistema educativo y sus relaciones con el orden social imperante $^{29}$.

Para lograr una mejor comprensión de esta problemática, se tomarán como base de análisis cinco estudios de caso: el conflicto registrado entre el colegio de Boyacá y los conventos de la provincia de Tunja, así como también las tensiones experimentadas entre el colegio de San José de Guanentá y los claustros ubicados en jurisdicción de la provincia del Socorro. Aunque existen otros ejemplos que se inscriben dentro de la temática planteada, se optó por los cinco casos referidos en razón a que ofrecen mayores posibilidades de información documental y bibliográfica que permite hacer un seguimiento más exhaustivo a las disputas registradas. En ese sentido, resulta mucho más complicado el análisis para los conventos ubicados en regiones como la Costa Caribe, Popayán y Pasto, por haber sido allí más prolongada la lucha de los republicanos para expulsar definitivamente a las fuerzas españolas.

27 Codificación nacional de todas las leyes de Colombia desde el año de 1821, Bogotá, 1925, t. IV, p. 327.

28 José David CORTÉs GUERRERO, Balance historiográfico sobre las relaciones Estado-Iglesia en Colombia desde la Independencia hasta finales del siglo XIX, en Historia y Sociedad, 18 (2010), pp. 163-190.

29 Virginia GUICHOT REINA, Historia de la educación: reflexiones sobre su objeto, ubicación epistemológica, devenir histórico y tendencias actuales, en Revista Latinoamericana de Estudios Educativos, 2-1 (2006), pp. 22-39. 
La metodología para llevar a cabo este trabajo de investigación incluyó un estudio descriptivo y cualitativo a partir de la consulta e interpretación de fuentes documentales de archivo, informes de gobierno, cruce de cartas, compendios normativos y la revisión de la prensa de esta época.

\section{LA VIRGEN DEL TOPO Y EL COLEGIO DE BOYACÁ}

Tradicionalmente, la provincia de Tunja se caracterizó por ser uno de los territorios con mayor fervor religioso que se vio reflejado en el gran número de conventos allí establecidos y en la desbordante devoción suscitada en torno a la Virgen de Chiquinquirá, sin duda la imagen más venerada en Colombia desde tiempos coloniales. Una prueba de la notoria presencia de la Iglesia en este territorio era el hecho de que hacia el año de 1778 se hallaban radicados en la ciudad de Tunja 319 miembros de este estamento ${ }^{30}$. Estos factores ayudan de alguna manera a explicar las reacciones que allí se generaron frente a la orden de supresión de conventos. No hay que perder de vista tampoco el hecho de que la existencia y funcionamiento de estas instituciones eclesiásticas favorecía el dinamismo de la economía regional ${ }^{31}$.

La devoción inspirada por la Virgen del Topo se originó en la ciudad de Tunja en la tercera década del siglo XVIII, cuando un Padre de la comunidad de los agustinos recoletos presenció la aparición de esta imagen mariana en una piedra que luego fue traída a la capilla de El Topo y, según varios testimonios, allí adquirió dilatada fama por los muchos milagros concedidos. El presbítero Osorio Nieto de Paz mandó hacer un relicario de plata y colocó allí la venerada piedra.

El 8 de febrero de 1822, en presencia del Padre fray Francisco de los Dolores Quevedo, se llevó a cabo el inventario de las pertenencias del convento del Topo. Allí, sin duda la imagen de más valor no solo espiritual sino material era la Virgen venerada de piedra ${ }^{32}$.

De acuerdo a lo estipulado por la ley de conventos suprimidos, a finales de 1822 las autoridades de Tunja solicitaron que la Virgen del Topo con su urna y alhajas fueran destinadas para el fomento del recién inaugurado colegio de Boyacá que desde sus inicios ya padecía serias dificultades financieras. En principio,

30 AgN, Sección Colonia, Fondo Censos Redimibles-Varios Departamentos, t. 6, ff. 261r, 367r.

31 David Bushnell, El Régimen de Santander..., op. cit., p. 262.

32 Marcelino GanUZa (fray), Monografía de las Misiones vivas de Agustinos Recoletos (Candelarios) en Colombia, siglo XVIII-XX, Bogotá, 1921, t. III, p. LIX. 
el gobierno dispuso que la imagen fuera trasladada con «la pompa y decencia posible» ${ }^{33}$.

Sin embargo, el rector del colegio José María Ramírez se adelantó a ese proyectado traslado formal y se dirigió hasta el convento de donde extrajo las urnas y demás alhajas de la Virgen de piedra que allí se veneraba. Ante este súbito incidente, el cabildo de la ciudad solicitó la restitución de la imagen pero el rector se negó reiteradamente alegando que era él el administrador designado por el gobierno central para responsabilizarse de la administración de los bienes de los conventos suprimidos. Ese mismo día se llevó a cabo el inventario de las alhajas en presencia del síndico procurador general de la ciudad de Tunja, Manuel Concepción de la Motta:

Un arquito frontero adornado con once topitos de esmeraldas engastadas en oro, 2 relicarios engastados en plata, 2 zarcillos de oro y perlas con piedrecitas de vidrio celeste.

El arco y columna guarnecidas con unos torzales de perlas con peso de 10 gramos, dos pinjantes de piedras de cristal y dos rosetitas de perlas con una cuenta de oro cada una en medio.

Otro arquito más inmediato a la piedra, dos topitos de esmeraldas engastadas en oro y una crucecita.

La corona de la Virgen y una cadenita de 7 esmeraldas engastadas en oro y 7 perlas grandes.

La corona de la Virgen es de plata sobredorada, tiene 16 esmeraldas engastadas en oro y 4 perlas grandes, una de ellas engastada en oro, 4 perlas chicas y 5 rosetas, y una crucecita de esmeralda engastada en oro.

La urna con 19 campanitas, una roseta de plata, 5 pinjantes de cristal, dos engastados en oro y tiene 4 piedrecitas ${ }^{34}$.

Se certificó que estas eran las mismas alhajas que semanas atrás se habían extraído del convento para ser llevadas al colegio. La procesión estaba programada para el día 11 de enero de 1823 pero por este inconveniente finalmente no se pudo realizar.

El gobernador provincial Mariano Olano debió intervenir en esta problemática y el rector finalmente accedió a devolver los elementos sagrados que estaban en su poder, los cuales fueron puestos en depósito en manos del síndico procurador general y, por mandato expreso del vicepresidente Santander, se lle-

\footnotetext{
33 AGN, Sección República, Ministerio de Instrucción Pública, t. 108, f. 698v.

34 AGN, Sección República, Fondo Ministerio de Instrucción Pública, t. 108, f. 700v.
} 
varon hasta la iglesia parroquial de Tunja. Aún se estaba a la espera de una nueva ley que despejara las dudas y confusiones en torno al destino de las alhajas de los conventos.

El cabildo de Tunja, entre tanto, solicitó al intendente del Departamento castigar al rector por el escándalo de haber regresado la imagen de la Virgen sin su urna y alhajas, situación que despertó profundo desconcierto y malestar en los fieles y en quienes desde tiempos coloniales habían efectuado donaciones para el culto divino ${ }^{35}$.

Acosado por las afugias económicas, a finales de 1823 el rector Ramírez alegó que la urna y las alhajas se podían vender en 1.500 pesos, recursos que en ese momento resultaban muy valiosos para evitar el cierre del colegio. Esta fue la justificación que en tono irónico elevó el directivo ante las altas esferas del gobierno: «[...] mientras el Soberano Congreso derriba un convento de estos grandes, y en lugar de alimentar seis u ocho vagos, se protege la enseñanza pública» ${ }^{36}$. El secretario del Interior terminó acogiendo esta petición e impartió instrucciones al intendente de Boyacá para que dispusiera de algunas de las alhajas a fin de conseguir dinero que permitiera mantener abierta al menos por algún tiempo la institución educativa, recursos que serían reintegrados mientras el Congreso fijaba nuevas opciones de financiación para los colegios. No obstante, el gobierno central advirtió que no era en esos momentos prudente despojar a la Virgen de todas las alhajas por ser una medida contraria a la opinión pública. Notificado de esta advertencia, el rector optó entonces por negociar otro tipo de elementos, como por ejemplo el sagrario del convento que fue avaluado en 400 pesos y vendido a mitad de este precio al cura de Tibaná, José Antonio Escobar ${ }^{37}$.

La situación del colegio de Boyacá en los últimos días del mes de noviembre de 1823 era realmente crítica:

[...] destrozado el edificio del colegio, sin agua, el lugar común metidísimo, ha sido indispensable refaccionarlo, poner el agua corriente y aunque se halla en disposición de abrirse, no hay dinero en cajas, no hay vicerrector, no hay cocineras, los inquilinos del colegio se hallan insolventes y el poco dinero que se recoge apenas basta para pagar la escuela y catedráticos que desde septiembre y octubre han abierto y están corrientes sus clases respectivas ${ }^{38}$.

\footnotetext{
35 AGN, Sección República, Fondo Ministerio de Instrucción Pública, t. 109, ff. 158r-168v.

36 Ibid., t. 108, f. 703r.

37 Ibid., t. 108, f. 707 r.

38 Ibid., t. 108, f. $753 \mathrm{v}$.
} 
Los fondos no alcanzaban para pagarle al vicerrector, ni al pasante ni al capellán. El rector se sentía incapaz de atender las funciones administrativas y de recaudo y, al mismo tiempo, impartir orden y disciplina a los estudiantes. Por sugerencia suya, se escogió al Padre Andrés María Gallo para que cumpliese simultáneamente las funciones de las tres vacantes.

Hacia 1825 el presupuesto disponible escasamente alcanzaba para cancelar el sueldo de 500 pesos para el profesor de la escuela de primeras letras y 200 pesos de gastos anuales pero no había cómo pagar a los cuatro catedráticos del colegio ni a las directivas del plantel. La situación se tornaba más incierta por el hecho de que el anterior rector no había entregado libros de cuentas y por ello era imposible reconstruir el estado de los pagos efectuados por los padres de familia para la manutención de sus hijos «[...] que en el día es excesiva por la suma carestía y precios subidos de todos los comestibles», gastos que al mes llegaban a los 88 pesos por los nueve internos existentes en ese momento. El déficit se había acentuado aún más al haberse rebajado la pensión anual por alumno de 80 a 64 pesos. Tampoco había cómo sufragar los gastos extraordinarios en reparos y limpieza de la vieja edificación ${ }^{39}$. Al año siguiente, el colegio debió cerrar temporalmente ${ }^{40}$.

En febrero de 1826, un estudiante de derecho canónico envió una nota al editor del semanario El Constitucional de Boyacá, en la cual expresaba su categórico rechazo tras la decisión de llevar la Virgen del Topo para el templo parroquial de la ciudad de Tunja siendo que, conforme a la ley, debía reposar en la iglesia del colegio, con lo cual la devoción traería más utilidad económica para la institución y a la vez los jóvenes contarían con una permanente protectora espiritual ${ }^{41}$.

Por estos días, el vice-rector solicitó al intendente se le entregara la imagen y las alhajas. No obstante, tras una súplica que elevara el cura de la iglesia mayor de Tunja al vicepresidente Santander, se decidió finalmente que la imagen debía permanecer en dicho templo ${ }^{42}$. Hacia 1842 el arzobispo de Bogotá Manuel José Mosquera prohibió todo culto a la Virgen de Piedra tras considerar que solo era una «ilusión óptica» ${ }^{43}$.

\footnotetext{
39 AGN, Sección República, Fondo Ministerio de Instrucción Pública, t. 106, ff. 276r-277r.

40 Ibid., t. 108, ff. 607r-608r.

41 El Constitucional de Boyacá, n. ${ }^{\circ}$ 31, Tunja, febrero 17 de 1826, p. 113.

42 AGN, Sección República, Fondo Peticiones y Solicitudes, t. 9, f. 71r.

43 Eugenio AyAPE De SAN Agustín (fray), Fundaciones y noticias de la Provincia de Nuestra Señora de la Candelaria de la Orden de Recoletos de San Agustín, Bogotá, 1950, pp. 196-198.
} 


\section{El COLEGIO DE BOYACÁ Y LAS ALHAJAS DE LOS CONVENTOS DE SANTO ECCE-HOMO, LA CANDELARIA Y MONGUí}

El convento de Santo Ecce-homo fue construido en 1620 por la comunidad de los Dominicos en jurisdicción de la población de Sutamarchán, en la provincia de Tunja. Este convento fue levantado en devoción a la imagen del Santo Eccehomo que había traído a esta jurisdicción el encomendero Juan de Mayorga, cuadro heredado de su abuelo quien en calidad de soldado español lo había obtenido en una batalla ocurrida en Roma hacia el año de 1527.

En atención a la ley del 28 de julio de 1821 de supresión de conventos, el gobierno nacional comisionó al juez político del cantón de Chiquinquirá, Francisco de Rojas, para que adelantara una inspección al convento, diligencia que fue acompañada por un grupo de tres senadores de la República. No obstante, los dominicos evitaron temporalmente la supresión del convento apoyándose en los testimonios de algunos campesinos de la región, quienes declararon que en dicho claustro permanecían más de ocho frailes ${ }^{44}$.

Dos semanas después de emanada la ley del 7 de abril de 1826, el intendente de Boyacá, Ignacio de Márquez, envió una comunicación al prior del convento ordenándole practicar un inventario formal y poner en depósito todas las pertenencias en manos de una comisión integrada por el alcalde de la villa de Leiva don José Ignacio Suárez, Antonio María Flórez y el escribano José María Vega. El registro del patrimonio del convento incluyó títulos, capellanías y los elementos sagrados descritos a continuación:

El cuadro de plata del Santísimo Ecce-Homo, una custodia de plata dorada con esmeraldas, tres cálices con sus patenas y cucharitas, un ornamento de damasco blanco y otro de damasco colorado con sus capas de coro, 34 casullas de distintos colores, 3 capas de coro, albas, roquetes, cíngulos, corporales, purificadores, incensario, el sagrario dorado con tres espejos, otros dos sagrarios, el trono del Señor con 6 laminitas de cristal en marcos dorados, el tabernáculo con tres cuerpos y siete cuadros dorados, barandilla verde del presbítero.

El altar del Santo Cristo con un Cristo, un San Luis Beltrán de bulto, San Jerónimo con su marco dorado, el púlpito dorado y cuadro de Santo Tomás, el cuadro de Nuestra Señora de Chiquinquirá y un sagrario dorado.

El altar dorado de Santo Domingo, el altar dorado y negro de las Ánimas, el altar de San José con fondo azul y un cuadro del santo con marco dorado.

La capilla de Nuestra Señora del Rosario con dos altares, siete cuadros, un retablo en tres cuerpos todo dorado, un sagrario, el camarín con su puerta y llave y la

44 Andrés MESAnZa (fray), Apuntes y documentos, pp. 117-129. 
Virgen del Rosario de bulto, un cajón con cinco vestidos de distintos colores para Nuestra Señora.

El altar de Nuestra Señora de la Salud con la imagen con su gargantilla, zarcillos y manillas de perlas falsas y frontal de madera dorado.

Un Santo Cristo de marfil, con cantoneras, todo en plata.

Ocho cuadros de los Apóstoles con sus marcos dorados.

En el edificio conventual estaba el coro con un cuadro dorado de Santo Domingo y el campanario con tres campanas y una más en el claustro. Biblioteca con 238 volúmenes ${ }^{45}$.

Al día siguiente del inventario, el 22 de abril, el prior del convento comunicó al superior provincial Domingo Barragán el atropello que habían padecido al ser despojados de las alhajas y al quedar sin un peso para el sustento diario. A su vez, Barragán transmitió esta inconformidad al vicepresidente Santander, reiterando los supuestos abusos y arbitrariedades cometidas por el intendente de Boyacá al querer suprimir el convento, una decisión que según el alto prelado era ilegítima por cuanto contaban con más de ocho religiosos al momento de promulgada la ley del 21 de julio de 1821 y no menos como lo habían hecho creer algunos testimonios. El problema radicaba en que algunos religiosos se hallaban ausentes pues estaban realizando labores de apoyo a los párrocos vecinos.

En consecuencia, Barragán solicitó la restitución de las alhajas y la anulación de las actuaciones del intendente a quien no dudó en calificar de ambicioso. Esta petición la reiteró teniendo como precedente el haber colaborado activamente esta comunidad religiosa en la causa de la Independencia no solo mediante la contribución económica al bando patriota sino también sufriendo opresiones y abusos por parte del gobierno español de Reconquista.

Ante estos reclamos de Barragán, el secretario del Interior José Manuel Restrepo reconoció los inobjetables servicios patrióticos prestados por la comunidad de los Dominicos pero de todos modos impartió instrucciones al intendente para que recogiera las pruebas y los testimonios necesarios a fin de comprobar que la orden de supresión proferida por el gobierno había sido legítima y apegada a la $l^{4} y^{46}$. Al parecer, de nada valieron los argumentos esgrimidos por el superior provincial pues el vicepresidente Santander envió el 18 de diciembre de este año de 1826 una comisión que se aprestó a ocupar el convento y a expulsar los religiosos.

Mediante decreto dictado el 30 de mayo de 1827, se dispuso que las cátedras del colegio de Boyacá quedaran incorporadas a la recién creada universidad que

\footnotetext{
45 Alberto ARIZA (fray), El convento del Santo Ecce-homo, Bogotá, 1966, p. 146.
}

46 Gaceta de Colombia, n. ${ }^{\circ} 245$, junio 25 de 1826, pp. 3-4. 
llevaba el mismo nombre, a la cual en adelante serían aplicadas todas las rentas del suprimido convento ${ }^{47}$. Los comisionados nombrados para este efecto tomaron posesión de estos bienes que quedaron en manos del rector, el presbítero Bernardo de la Motta.

Esta decisión generó una masiva protesta de los devotos de la villa de Leiva, Sutamarchán y demás poblaciones ubicadas en los alrededores del convento. Con el fin de aplacar estas manifestaciones de rechazo a la decisión oficial, el rector optó por trasladar la sagrada imagen del Santo Ecce-homo a la ciudad de Tunja bajo el argumento de que era imperioso salvaguardarla ante el estado de ruina del convento que era una constante amenaza. Se programó la fecha del 19 de abril de 1828 para llevar a cabo esa diligencia oficial.

Sin embargo, al correr este rumor las mencionadas comunidades se declararon en estado de alarma y, para impedir que se llevaran la santa imagen, se apostaron en las puertas del templo del convento, hecho que fue calificado por el rector como una «asonada». Primero fueron los vecinos de Sutamarchán los que intentaron sacar violentamente la imagen sagrada pero no lo lograron ante la resistencia del depositario. Al poco tiempo llegaron las autoridades y un nutrido grupo de más de 100 habitantes de la villa de Leiva, cuya fuerza hizo al fin posible violentar la puerta y alcanzar el objetivo propuesto. El resignado depositario solo exigió que la municipalidad de Leiva firmara un acta en el que dejara constancia de su aleve conducta.

La imagen fue llevada por la gente hasta la cabecera municipal de villa de Leiva y allí sus autoridades propusieron al rector que estaban dispuestas a ofrecer 100 pesos con tal de que el cuadro quedara al cuidado de la iglesia mayor de aquella villa, propuesta que fue respaldada por los vecinos de Sáchica. Estos fueron algunos apartes del memorial suscrito por los feligreses con miras a que se les respetara su arraigada tradición religiosa:

¡Quién con más fervor se podrá postrar ante el Ara de su clemencia que esta parroquia acostumbrada a ello desde su infancia? ¡Y quién con más fervor le podrá pedir, cuando ha sido y es la piscina en nuestros males, y el tesoro descubierto en nuestras necesidades? A venerar a este Señor nos hemos acostumbrado; esto nos lo enseñaron nuestros padres; esto aprendimos de nuestros mayores; en alhajar aquella iglesia consumieron nuestros parientes intereses, y últimamente en señal de veneración y satisfechos de su patrocinio, ofrecimos visitar esta Sagrada Imagen anualmente por voto común de todos los pueblos. Y no podemos cumplir con este voto

47 Gaceta de Colombia, n. ${ }^{\circ} 295$, junio 12 de 1827, p. 1. 
costeándolo en la distancia que se presenta. Porque aquí lo puede visitar el sano y el enfermo, y el rico y el pobre, el esforzado y el tullido, que todo lo facilita la cercanía, lo que no sucederá, estando en Tunja $[\ldots]^{48}$.

Para Motta, esta acometida popular era una acción que atentaba contra el derecho legítimo de propiedad de la universidad y, por tanto, el intendente de Boyacá debía aplicar medidas urgentes para contener esos excesos y hacer cumplir la orden de restitución del Cristo venerado.

El nuevo intendente, Cristóbal de Vergara, intervino en esta álgida controversia ordenando que la imagen quedara a cargo del rector, quien para el efecto envió una comisión hasta villa de Leiva para que llegara a un acuerdo con los dirigentes políticos de este lugar. Difundida allí la noticia de esta diligencia, de nuevo se formaron tumultos que exacerbaron aún más los ánimos. La municipalidad, entre tanto, nombró dos delegados para tratar directamente el asunto. Motta criticó a las autoridades de Leiva por autorizar las asonadas y por haber infringido el derecho de propiedad de la universidad y lo dispuesto en las leyes, especialmente el decreto dictado el 24 de noviembre de 1826 por el presidente Simón Bolívar. Por su parte, los representantes de la villa prometieron que el 8 de mayo siguiente devolverían la imagen al convento a fin de permitir que esa misma fecha, como ya era costumbre por años, los pueblos de aquel cantón se aprestaran a visitarla para renovar sus devociones y promesas ${ }^{49}$.

Finalmente, el rector accedió a que el Cristo venerado regresara a su sitio natural. La restitución se efectuó en presencia del cabildo mientras que el rector se comprometió a no sacar nunca más dicha imagen. El intendente, entre tanto, estaba convencido de que, si las iglesias eran despojadas de sus reliquias, debían cerrarse porque ni la comunidad ni el colegio tenían cómo conservarlas. Creía además que los pueblos agradecerían mucho el que se dejasen adornados los templos pues estaban acostumbrados a adorar esas imágenes y era para ellos muy doloroso ver cómo se «desnudan y arruinan». Se planteó entonces que los curas se hiciesen cargo de la conservación de esas reliquias y que lo que se hubiese de vender o sacar de esos templos fuera acordado previamente con los pobladores a quienes era justo incluirlos en el proceso de venta. Con estas decisiones el gobierno provincial podía garantizar el orden y la tranquilidad pública y, a su vez, el rector ganaría la confianza y gratitud de la comunidad que asimismo podía verse reflejada en apoyo económico para los colegios y para las universidades. Meses

\footnotetext{
48 Alberto ARIZA (fray), El convento del Santo Ecce-homo, p. 157.

49 AGN, Sección República, Fondo Negocios Eclesiásticos, t. 1, ff. 816r-818v.
} 
antes la municipalidad de Leiva había propuesto sin mucho éxito hacerse cargo de las edificaciones de los conventos de San Francisco y San Agustín para destinarlos a usos públicos.

El secretario del Interior, José Manuel Restrepo, coincidía con el intendente en pensar que el colegio y la universidad de Boyacá debían dejar los cuadros y reliquias en los conventos para que el pueblo pudiese continuar el culto mantenido durante varias décadas. El rector debía hacer inventario de los elementos sagrados que estaban en su poder y entregarlos a los curas para que se encargaran de su custodia pero estas alhajas seguirían siendo propiedad del colegio y de la universidad, tal como se había estipulado legalmente. Restrepo ordenó además mirar si había alhajas de oro, plata o piedras preciosas que no fueran imprescindibles en las iglesias o que no fueran veneradas, para proceder entonces a venderlas en beneficio de las instituciones educativas.

Por su parte, el rector defendió sus actuaciones aduciendo que era consciente del culto que se le rendía a la imagen sagrada y que en ningún momento había pensado sacarla. Antes por el contrario, había designado a un religioso de la comunidad para cuidarla y asegurar que se celebrara misa en su nombre. Sin embargo, Motta mantenía vivo su temor de que esta petición de restitución de imágenes sagradas se repitiera en otros templos y conventos suprimidos, lo cual según él provocaría una andanada de líos jurídicos y alteraciones de la tranquilidad pública, factores que amenazaban con obstruir el sostenimiento económico del colegio y la universidad de Boyacá ${ }^{50}$.

Finalmente, el colegio-universidad dio a conocer al intendente una propuesta presentada por Isidro Chaves, cura de la parroquia de Sutamarchán, para que quedara a su cargo el cuidado del convento, junto con la sagrada imagen y demás elementos del culto divino. El rector accedió a esta solicitud bajo la condición de que el colegio no asumiera ningún gasto de conservación ni mejoramiento de los edificios pero al mismo tiempo aprovechó la ocasión para reafirmar su derecho sobre estas edificaciones y sobre las reliquias y alhajas. El cura Chaves únicamente fungiría como depositario beneficiándose de lo obtenido por el culto religioso.

En julio de 1828, el Libertador Simón Bolívar derogó las leyes que se habían dictado contra los conventos menores, lo cual permitió que la comunidad dominicana regresara al convento del Santo Ecce-homo restableciendo su vida regular el 8 de octubre de ese año. No obstante, la restitución fue efímera debido a la polarización política existente por cuanto en enero de 1832 la Convención

\footnotetext{
50 AGN, Sección República, Fondo Ministerio de Instrucción Pública, t. 109, ff. 190r-195v.
} 
Nacional anuló los decretos de Bolívar y, por consiguiente, el convento quedó nuevamente en manos del gobierno.

Al cabo de cinco años, el cura de Hatoviejo, Buenaventura Sáenz, obtuvo en remate público el convento. Hacia 1840, Sáenz encomendó en depósito la sagrada imagen al cura de Sutamarchán con la condición de que su parroquia colaborara en la conservación y urgente reparación del convento teniendo como meta reintegrar allí la imagen.

Gracias a las gestiones adelantadas en 1855 por fray Benedicto Bonilla, la comunidad religiosa recuperó el convento por la donación que realizara el cura Sáenz. El acuerdo se selló el 25 de junio por medio de escritura pública y la imagen fue entregada al prelado dominicano en presencia del juez letrado del cantón de Leiva, Agustín Landínez. Para celebrar este proceso de restitución, con gran asistencia del feligresado se llevó a cabo una procesión mediante la cual el Santo Ecce-homo fue conducido de la parroquia de Sutamarchán a su antigua sede ${ }^{51}$. El convento fue suprimido nuevamente en 1858 y volvió a manos del cura Sáenz y sus herederos. Finalmente, hacia 1909 la imagen fue devuelta a la iglesia parroquial de Sutamarchán.

Las disputas en torno a las alhajas se extendieron a otras dos comunidades religiosas de la provincia de Tunja: el convento del desierto de la Candelaria a cargo de los agustinos recoletos y el convento de Monguí manejado por los franciscanos. Hacia 1826, el rector del colegio de Boyacá, Bernardo de la Motta, recibió la noticia de la pretensión de los vecinos de la parroquia de Ráquira de extraer del convento del desierto la imagen de la Virgen de la Candelaria ${ }^{52}$ para trasladarla a la iglesia de dicha parroquia. De inmediato, el rector reportó este incidente al intendente departamental con el propósito de que este funcionario tomara las medidas de prevención a fin de impedir que los feligreses cumplieran su cometido. Este gobernante nombró una comisión que debía trasladarse hasta el desierto con el objeto de contener los ánimos exaltados. Al final, la imagen no fue extraída pero los religiosos del convento recibieron varios insultos de la comunidad. Motta pidió

51 Alberto ARIZA (fray), El convento del Santo Ecce-homo, pp. 157-159.

52 A finales del siglo XVI, un grupo de ermitaños agustinos encargó al pintor italiano Francisco del Pozo, residente en la ciudad de Tunja, la realización del cuadro de Nuestra Señora de la Candelaria. La pintura fue exhibida el día de la inauguración de la capilla del convento y desde ese momento fue muy visitada por los fieles en razón a la gran cantidad de milagros. Basilio Vicente de Oviedo, Cualidades y Riquezas del Nuevo Reino de Granada, Bucaramanga, 1990, p. 215; Eugenio AYAPE DE SAN AgUSTín (fray), Historia del Desierto de La Candelaria Bogotá, 1935, pp. 20-21; Antonio CaCua Prada, Los Agustinos Recoletos en la bistoria de Colombia, en Boletín de Historia y Antigüedades, 826 (2004), p. 826. 
encarecidamente al gobierno provincial brindar apoyo y protección al colegio para defender sus intereses y contener tantos ultrajes y ataques.

En virtud de la ley expedida el 7 de abril de 1826, fue ordenada la supresión del convento franciscano de la población de Monguí. Por instrucciones del intendente Márquez, sus alhajas e imágenes sagradas fueron llevadas a la ciudad de Tunja y luego inventariadas por el tesorero departamental Diego Gómez, el juez político de Sogamoso y el cura fray Bartolomé Niño. En presencia de varios religiosos y de algunos vecinos tunjanos, se procedió a desprender las alhajas que pendían del cuadro de la Virgen de Monguí ${ }^{53}$, se inventariaron junto a otras existentes en el convento y se entregaron al rector del colegio de Boyacá en vista de que los curas de Tunja no querían encargarse de la custodia de estos elementos sagrados y en Monguí no había seguridad para mantenerlos allí. Lo más valioso era la corona de la Virgen, adornada con 335 esmeraldas y 104 perlas finas. Según cuenta la tradición, las joyas de esta imagen sumaban en total 648 esmeraldas «gotas de aceite», 17 amatistas, 800 perlas, 744 perlas de rostrillo, 18 rubíes, 145 maporas, 1.000 castellanos de oro y 500 castellanos de plata ${ }^{54}$.

Luego, a los dos años, tras la orden dictada por el general Bolívar para la restitución de los conventos, todos los elementos sagrados fueron devueltos a su sitio de origen pero en el inventario faltó una lamparita de plata que se extravió en la iglesia del colegio en una noche de graduaciones. Años más tarde, hacia 1838, se suscitó un escándalo en el que resultó involucrado el intendente de Boyacá de esa época, Ignacio de Márquez, a quien se le acusó de haberse apropiado de algunas alhajas. Márquez pudo demostrar su inocencia y consideró esos señalamientos como una campaña de difamación emprendida por sus más acérrimos contradictores políticos ${ }^{55}$.

\section{El COlegio SAN José de Guanentá y las alHajas DE LOS CONVENTOS DE LA PROVINCIA DEL SOCORRO}

La provincia del Socorro fue desde tiempos del dominio hispánico una de las más prósperas de la Nueva Granada. Su jurisdicción había alcanzado un alto nivel de poblamiento con un predominio indiscutible de gentes blancas y mes-

53 El lienzo de Nuestra Señora de Monguí fue enviado en el siglo XVI por el Rey Carlos V para el culto de la doctrina de indios. Desde muy temprano adquirió esta imagen una dilatada fama por sus innumerables milagros. Basilio Vicente de OvIEDO, Cualidades y Riquezas..., op. cit., p. 174.

54 Javier OCAMPo LóPEZ, El Colegio de Boyacá en 100 pildoritas históricas, Tunja, 2003, p. 10.

55 José Ignacio MárQUEZ, Las alhajas del convento de Monguí en 1826, Bogotá, 1868, pp. 1-17. 
tizas que se vio reflejado en la consolidación de sus centros urbanos y en un inusitado auge de parroquias ${ }^{56}$. En contraste con la provincia de Tunja, en la provincia socorrana apenas sobrevivían dos conventos para el periodo objeto de este estudio: el convento de los capuchinos y el de San Francisco. Según el censo de 1778, en esta provincia del nororiente neogranadino el número de miembros del estamento eclesiástico no pasaba de $70^{57}$.

El convento de los capuchinos fue fundado en la villa del Socorro en 1781 en medio del fragor de la revuelta de los Comuneros que sacudió a esta provincia. El Padre Joaquín de Finestrad fue uno de sus más entusiastas impulsores. Él había cumplido, por encargo de las autoridades virreinales, una activa labor pastoral a fin de apaciguar los ánimos de los insurrectos Comuneros que se habían alzado en contra de las cargas impositivas dispuestas por el gobierno español en el marco de las reformas borbónicas ${ }^{58}$.

La edificación fue construida con aportes del erario Real y de los vecinos no solo de la villa sino también de los pueblos aledaños ${ }^{59}$. Durante su corta existencia, el convento padeció serios aprietos para sostenerse económicamente, además del escaso número de religiosos ${ }^{60}$.

La polarización generada por la lucha política y militar por la Independencia marcó el ocaso de este convento. En su mayoría, la comunidad capuchina estaba compuesta por españoles peninsulares y este hecho fue determinante en la confrontación que se suscitó por estar en medio de una región levantisca y adepta a la causa de la Independencia. En julio de 1810, durante las primeras manifestaciones de autonomía política, la edificación se convirtió en sitio de refugio para las autoridades españolas que huían del ataque del pueblo enardecido. En esta ocasión, los frailes fueron objeto de toda clase de insultos y desprecios, razón por la cual huyeron recogiendo en sacos $\ll[. .$.$] los caudales, las joyas, los vasos sagra-$ dos y demás objetos valiosos del culto» ${ }^{61}$.

Hacia 1816, cuando los españoles reconquistaron el poder, lograron regresar algunos religiosos al convento que se hallaba bastante deteriorado en su es-

56 Basilio Vicente de Oviedo, Cualidades y Riquezas..., op. cit., pp. 233-235.

57 AGN, Sección Colonia, Fondo Censos Redimibles-Varios Departamentos, t. 6, ff. 261r, 367r.

58 Joaquín de FineSTRAD, El Vasallo Instruido en el Estado del Nuevo Reino de Granada y en sus respectivas obligaciones, Bogotá, 2000.

59 AGN, Sección Colecciones, Fondo Enrique Ortega Ricaurte, Conventos, caja 24, carpeta 5, ff. 23r-26v; Antonio AlCácer (fray), El convento del Socorro. Primer convento Capuchino en América (17811819), Bogotá, s.f., p. 59.

60 José MARTínEZ, El convento realista de Padres Capuchinos del Socorro, Bogotá, 1971, pp. 1-64.

61 Horacio Rodríguez Plata, La antigua provincia del Socorro y la Independencia, Bogotá, 1963, p. 34. 
tructura física ${ }^{62}$. Después del triunfo obtenido por los patriotas en la batalla de Boyacá el 7 de agosto de 1819, los capuchinos abandonaron definitivamente su claustro.

En atención al mandato dictado por el vicepresidente Santander, en junio de 1821 el cura del Socorro solicitó la entrega del edificio de los capuchinos junto con las alhajas y enseres de la iglesia ${ }^{63}$. No obstante, al mes siguiente salió publicada la referida ley que ordenaba disponer de las pertenencias de los conventos menores para beneficio de la educación pública. Esto implicaba que las alhajas del convento de los capuchinos debían pasar a manos del colegio que debía fundarse en la provincia. Sin embargo, la escogencia de la sede para esta institución educativa causó una álgida disputa entre San Gil y Socorro, los principales epicentros urbanos de dicho marco territorial.

El delegado de San Gil lanzó serias críticas a El Socorro, la capital de dicha provincia, por no contar en ese momento con sujetos pudientes ni suficientes rentas de propios para el establecimiento del colegio. La posición central, la holgada disponibilidad de recursos oficiales, el entusiasmo del vecindario, el apoyo incondicional de varios benefactores y la acreditada experiencia en la implementación de cátedras y escuelas de primeras letras, fueron algunos de los argumentos esgrimidos por el emisario de la sala capitular de San Gil ${ }^{64}$.

Los cabildantes del Socorro, entre tanto, se defendieron de estos señalamientos aduciendo que la crisis económica, el déficit presupuestal y la falta de pudientes en esta villa no eran circunstancias meramente fortuitas sino que fueron consecuencia de la valentía, el sacrificio y el patriotismo de sus habitantes puestos a prueba en la revuelta Comunera, en las manifestaciones emancipatorias de julio de 1810 y en las opresiones vividas durante el período de la Reconquista española. Se quiso además hacer énfasis en que los socorranos venían contribuyendo con los gastos que implicaba el mantener allí la sede del gobierno provincial. De todos estos infortunios económicos, políticos y militares, argüía el cabildo socorrano, se habían librado los sangileños, quienes además contaban con el alivio de más de 1.500 pesos en rentas del puente sobre el río Fonce y de varios pasos de canoas.

Finalmente, la gran mayoría de pueblos de la provincia adhirieron a la idea de ubicar el colegio en la villa de San Gil, y ese favoritismo fue crucial para incli-

\footnotetext{
62 Ibid., pp. 247-264.

63 AGN, Sección República, Fondo Negocios Administrativos, t. 6, f. 534r.

${ }^{64}$ Juan de Dios ARIAS, Colegio de San José de Guanentá. Reseña histórica, Bucaramanga, 1943, pp. 9-22.
} 
nar la balanza en la decisión que se dio a mediados de mayo de 1824 al crearse allí el colegio de San José de Guanentá6 ${ }^{65}$.

$\mathrm{Al}$ conocer la intención de los sangileños de llevarse las alhajas del convento de los capuchinos, las autoridades del Socorro adoptaron algunas medidas preventivas e instaron al cura parroquial Pedro Antonio Rueda a no entregar bajo ninguna circunstancia estos elementos sagrados sin previa orden expresa del gobierno central. Los temores finalmente se hicieron realidad y se llevó a cabo el despojo violento en el que los socorranos se vieron ultrajados «por el populacho de San Gil que tumultuariamente arrebató sus bienes».

En octubre de 1824 Francisco Otero, cura de la villa de San Gil y rector del colegio de San José de Guanentá, reiteró al intendente de Boyacá la solicitud para que le fueran entregadas oficialmente todas las alhajas y paramentos del convento de los capuchinos, conforme a lo dispuesto por la ley de supresión de conventos menores. Esta pretensión suscitó la férrea oposición de Narciso García, procurador y apoderado del cabildo del Socorro, quien consideraba que todo esto era producto de los «bajos y mezquinos» resentimientos que habían abrigado algunos vecinos sangileños contra los socorranos y de la «antigua antipatía» que había imperado entre ambas poblaciones.

Vale recordar que, efectivamente, esta no era la primera vez que estas dos localidades se trenzaban en agudas rivalidades en torno a obtener la supremacía política en esa provincia del nororiente neogranadino pese a ser poblaciones relativamente cercanas pues tan solo las separaba un corto camino de cuatro leguas. En 1711, por ejemplo, los sangileños se opusieron insistentemente a la pretensión del Socorro en querer alcanzar el título de ciudad y en 1763 también rechazaron la meta de los socorranos en que se les concediera el título de villa, reconocimiento finalmente logrado en 1771 . Esta nueva división política generó varias diferencias en materia de límites. Férrea resistencia se observó también en San Gil cuando en 1810 El Socorro declaró tempranamente su independencia y cuando al año siguiente aspiró a la erección de obispado ${ }^{66}$.

Según García, el intendente de Boyacá había ordenado la entrega de las alhajas al colegio de San Gil tras desconocer los citados antecedentes y sin oír previamente al cabildo del Socorro. Para él era muy claro que estas alhajas debían beneficiar a la misma vecindad que con tanto esfuerzo había contribuido a la consecución de estos elementos indispensables para el culto divino. Se reiteró

65 Gaceta de Colombia, n. ${ }^{\circ}$ 139, junio 13 de 1824, p. 1.

66 Horacio RodrígUeZ PlaTA, La antigua provincia del Socorro..., op. cit., pp. 678-680. 
además que en 1819 el Libertador Simón Bolívar había dispuesto que el convento debía destinarse en beneficio de la educación pública.

Según García, se había ignorado «maliciosamente» la solicitud que formulara el cabildo del Socorro al Congreso de la República para establecer un colegio en esta población. Igualmente se buscó amparo en los artículos 177 y 178 de la Constitución $\mathrm{Nacional}^{67}$ en los que se estipulaba que nadie podía ser despojado de su legítima propiedad. Por consiguiente, se tenía la convicción de que la ley del 28 de julio de 1821 no podía derogar las preexistentes disposiciones promulgadas a favor de la villa del Socorro, además del hecho de que al parecer aquella ley tampoco se aplicaba al claustro de los capuchinos pues este era un convento máximo con más de diez religiosos.

En los últimos meses, el pueblo socorrano había trabajado en la refacción del edificio y en la recaudación de auxilios con miras a la instalación de su propia casa de estudios, de acuerdo a la autorización que para el efecto había emitido el gobierno central. Como resultado de esa insistente gestión, finalmente el 18 de octubre de 1823 fue abierta en esta villa la cátedra de filosofía bajo la dirección del Padre Félix Gómez, un paso fundamental para alcanzar dos años después la categoría de colegio público ${ }^{68}$.

García estaba convencido de que el vecindario de San Gil no necesitaba de estos bienes del convento porque se hallaban en mejor situación económica y además porque la iglesia parroquial contaba con suficientes alhajas, tanto como para suplir los templos de otros cantones. Se exigió al gobierno central la restitución inmediata de los bienes arrebatados y adicionalmente se pidió reparación al agravio padecido por la decisión tomada de manera precipitada por la intendencia de Boyacá ${ }^{69}$.

El 7 de octubre de 1824 el Congreso de la República decidió que las alhajas de los capuchinos conducidas al colegio de San José de Guanentá fueran utilizadas para beneficiar a este último plantel mientras se establecía formalmente el colegio del Socorro. El cabildo socorrano aceptó esta decisión pero bajo la expresa condición de que se cumpliera a cabalidad con el fin de no entorpecer el proyecto educativo local ${ }^{70}$.

67 Constitución de la República de Colombia, Rosario de Cúcuta, 1821, pp. 59-60.

68 Luis Horacio LóPEZ DomíNGUEZ, Obra educativa de Santander 1819-1826, Bogotá, 1990, vol. I, p. 130.

69 AGN, Sección República, Fondo Ministerio de Instrucción Pública, t. 123, ff. 78r-86v.

70 Ibid., t. 123, f. 119r. 
Finalmente, luego de haber demostrado que contaban con suficientes fondos a nivel local y provincial, el 15 de enero de 1826 el vicepresidente Santander firmó el decreto que dio vida institucional al colegio de la villa del Socorro cuya sede sería el convento de los capuchinos «[...] devolviéndoseles las alhajas que no se habían enajenado y se hayan dado provisionalmente a alguna otra casa de estudios» ${ }^{71}$.

Con base en el pronunciamiento del 7 de octubre de 1824 y de este decreto de principios de 1826, los socorranos exigieron con más ahínco la devolución de las alhajas. Ante tal expectativa, el 8 de mayo de 1826 el intendente de Boyacá Francisco Padilla, en aras de la deseada paz y armonía que debía primar entre socorranos y sangileños, decidió que las alhajas que antes pertenecían al convento de los capuchinos y que habían pasado al colegio de San José de Guanentá, fueran divididas paritariamente entre ambas instituciones educativas, para lo cual se impartieron instrucciones al gobierno provincial a fin de que se procediera a realizar el avalúo por personas imparciales, disponiéndose además que, aquellas alhajas que no eran «divisibles», se aplicaran al colegio que más las necesitare, responsabilizándose de satisfacer la mitad de su valor al otro plantel ${ }^{72}$.

En presencia de testigos, el síndico procurador general del Socorro llevó a cabo el inventario, en cuyo listado se hallaban los siguientes ornamentos sagrados: una custodia, unos cálices, un copón, unas vinajeras, un incensario, un ornamento de seda, una campana mayor, varios ornamentos al servicio de la capilla de dicha hermandad y las imágenes de San Francisco, San Antonio, Santa Rosa, Jesús Nazareno, San José y el beato Lorenzo de Brindi ${ }^{73}$.

Hacia el mes de noviembre de 1827, los gobiernos de Socorro y San Gil aún mantenían viva su lucha por las alhajas. La librería que tenían los capuchinos en su convento también había sido trasladada a San Gil. En ese momento, el avaluó de las alhajas retenidas en el colegio de San José de Guanentá ascendía a 820 pesos representados en: una mesa de sacristía valorada en 200 pesos, un reloj de campana en 150 pesos, un cáliz en 20 pesos, 4 ornamentos en 100 pesos, una imagen de bulto de San José y otra de San Antonio en 100 pesos, una campana en 150 pesos y varios libros avaluados en 100 pesos $^{74}$.

Narciso García, apoderado de la villa del Socorro, seguía insistiendo en que, erigido el colegio en la antigua sede del convento de capuchinos, era imperioso tra-

\footnotetext{
71 AGN, Sección República, Fondo Ministerio de Instrucción Pública, t. 123, f. 156r.

72 Ibid., t. 123, f. 162r.

73 Ibid., t. 123, f. 163 r.

74 Ibid., t. 106, ff. 770r-772r.
} 
mitar la devolución de todas las alhajas, utensilios y paramentos que fueron trasladados al colegio de San Gil. Ya la municipalidad lo había reclamado ante el gobierno provincial y, ante la negativa de esta instancia, fue necesario recurrir a la Corte Superior de Cundinamarca y Boyacá. Este tribunal dilató por varios meses más la decisión hasta que finalmente en junio de 1828 se declaró incompetente para tratar sobre este asunto ${ }^{75}$. Ante tal incertidumbre jurídica, se recomendó acudir ante el gobierno central para que se pronunciara sobre el caso y este fue su dictamen:

[...] el derecho originario que los moradores del Socorro tienen a los intereses que se reclaman con exclusión de los de la villa de San Gil y los alumnos de su colegio. Cada cual adorna su casa con lo que le pertenece en propiedad sin que la ley ni el buen orden le permita alhajarla o paramentarla con lo que al vecino le pertenece en la suya sino en el caso en que éste expresamente lo consienta. El pueblo del Socorro edificó a su costa lo que hoy es colegio de los educandos, sus hijos, y con sus propios bienes de fortuna la alhajó y paramentó sin el auxilio forzado o voluntario del de San Gil. Consiguientemente, pertenecen a su colegio con toda propiedad y dominio no tan solo los pocos muebles que le fueron reservados sino también los que se trasladaron al colegio de Guanentá de un modo provisorio e interinario ${ }^{76}$.

El 22 de enero de 1832, en el inventario que por mandato del Gobierno central se efectuó en el colegio del Socorro, los peritos dejaron constancia de que en el colegio de San José de Guanentá aún reposaban libros y alhajas que eran del convento de capuchinos, elementos que a la fecha no habían sido devueltos como lo prescribía el decreto proferido por el vicepresidente Santander a principios de 1826. En total, eran 267 libros, la mayor parte de ellos de carácter religioso aunque también se hallaba allí el Diccionario de Lebrija, la Recopilación de Leyes de Indias, Don Quijote de la Mancha y algunas comedias de Calderón de la Barca. De las alhajas, en esta ocasión únicamente se registró «[...] una diadema sembrada de piedras preciosas, esmeraldas algunas, que pesa juntamente con las piedras once onzas, una ochava y media, avaluada en catorce pesos» ${ }^{77}$.

Ampliamente conocido fue también el enfrentamiento sostenido entre el colegio de San José de Guanentá y el convento de San Francisco ubicado en Vélez. En noviembre de 1821 un grupo de más de ochenta vecinos de esta ciudad exigieron al gobierno central la restitución del suprimido convento de San Francisco, clamor al cual se sumó el cabildo en pleno y, desde luego, la comunidad

\footnotetext{
75 AGN, Sección Colecciones, Fondo Enrique Ortega Ricaurte, Conventos, caja 24, carpeta 5, f. 55r.

76 AGN, Sección República, Fondo Negocios Eclesiásticos, t. 5, f. 259r.

77 Horacio RodrígueZ Plata, La antigua provincia del Socorro..., op. cit., pp. 692-695.
} 
franciscana que a través de su máximo representante reiteró el hecho de que este siempre había sido un convento formal con más de ocho religiosos, poniendo además de relieve el auxilio espiritual al servicio de los veleños desde los tiempos de la fundación de la ciudad y el gran aporte a la educación con el funcionamiento de la escuela de primeras letras que impartía educación a ochenta niños ${ }^{78}$.

$\mathrm{Al}$ parecer, estas protestas fueron desestimadas pues el 12 de febrero de 1822 se llevó a cabo el inventario de los bienes del convento, cuyo avalúo fue estimado en 1.401 pesos. Dentro de las alhajas más preciadas cabe destacar una custodia de plata de 66 onzas con adornos de piedras francesas y esmeraldas valorada en 99 pesos, una corona de la Virgen con un arco de estrellas de 25 onzas tasada en 33 pesos y un arco de sagrario y centellero de 83 onzas $^{79}$.

En atención al clamor de la comunidad de fomentar la educación pública en esta ciudad y, a la solicitud que en tal sentido elevara el síndico procurador general, el vicepresidente Santander finalmente dictó un decreto el 4 de octubre de 1822 en el que dispuso que el convento suprimido fuera transformado en una casa de educación con una escuela de primeras letras y una cátedra de gramática. Se decidió que de los capitales de este convento se destinaran 15.000 pesos para dicha institución educativa ${ }^{80}$. En respuesta a la anterior directriz, el 17 de mayo del año siguiente el juez político del cantón de Vélez formalizó la entrega del edificio y de las alhajas al Padre fray Cirilo Bustos, designado como maestro de la cátedra de gramática ${ }^{81}$.

En el álgido debate suscitado en torno al sitio donde se erigiría el colegio de la provincia del Socorro, se pensó también en la posibilidad de ubicarlo en la ciudad de Vélez gracias a su buen clima y a que allí existía un edificio adecuado para tal propósito pero, por hallarse en el extremo de la provincia, se concluyó que no sería la mejor opción. Como bien se ha dicho, finalmente la decisión se inclinó a favor de fundar el colegio de San José de Guanentá en la villa de San Gil, de conformidad con el decreto promulgado a mediados de mayo de $1824^{82}$.

Habiendo ganado esta villa la sede de la nueva institución educativa, sus directivas afanosas por conseguir recursos enfocaron la mirada no solo hacia el convento

78 AgN, Sección República, Fondo Negocios Eclesiásticos, t. 5, ff. 322r-333v.

79 Ibid., t. 5, ff. 338r-348r.

80 Luis Horacio López Domínguez, Obra educativa de Santander, pp. 188-189; Detalles del inventario efectuado en octubre de 1822 pueden verse en: AGN, Sección República, Fondo Negocios Eclesiásticos, t. 5, ff. 283r-290v.

81 Luis Carlos Mantilla, Los Franciscanos en Colombia, p. 336; AGN, Sección República, Fondo Negocios Eclesiásticos, t. 5, f. 429r.

82 Gaceta de Colombia, n. ${ }^{\circ} 139$, junio 13 de 1824, p. 1. 
de los capuchinos ubicado en la villa del Socorro sino también hacia los caudales del convento de Vélez. Así entonces, ante la campaña emprendida por el rector del colegio de San José de Guanentá, los veleños se escudaron en el hecho de que ya habían recibido autorización del gobierno nacional para fundar casa de educación y escuela de primeras letras con base en los bienes de los conventos suprimidos.

El mencionado rector había comisionado el 18 de octubre de 1824 al ciudadano Braulio Navarro en calidad de apoderado con la respectiva orden emanada del gobierno provincial para tomar posesión de las pertenencias del convento. No obstante, el depositario de estos elementos sagrados se negó exigiendo que primero tenía que ver el decreto superior que daba vía libre a esta entrega. A los pocos días, con un oficio del gobernador provincial en sus manos, volvió el apoderado con algunos peones y mulas pero el depositario se opuso una vez más, razón por la cual debió regresar en medio de amenazas e improperios de los veleños que insistían en que ellos ya tenían su casa de estudios a la cual podían destinarse las alhajas. Otero prometió no volver a esta ciudad sin antes tener en su poder la lista oficial de las alhajas que llevaría y de aquellas que debían dejarse por ser indispensables para el culto divino.

Las autoridades y los habitantes de Vélez, entre tanto, reiteraron su justo derecho a no ser despojados y a disponer de los bienes existentes en su propia ciudad para el beneficio de la instrucción de sus jóvenes. Al igual que lo expresado por los socorranos, ellos estaban convencidos de que la villa de San Gil disponía de fondos suficientes para establecer y conservar su colegio ${ }^{83}$.

En respuesta a este clamor, el vicepresidente Santander resolvió el 30 de octubre de 1824 que, hasta nueva orden del Congreso de la República, las alhajas y paramentos del convento de San Francisco quedaran para el servicio de la casa de educación fundada en esta ciudad.

Sin embargo, de nuevo el ambiente se tornó confuso tras conocerse la resolución fechada el 22 de febrero del año siguiente mediante la cual el poder ejecutivo central decidió que los bienes del convento se entregaran al rector del colegio de San José de Guanentá, lo cual reavivó las airadas protestas de las autoridades y de los habitantes de Vélez. El vicepresidente Santander debió atemperar los ánimos tras aclarar que esta medida no derogaba la del 30 de noviembre, es decir, de estos bienes quedaban excluidas las alhajas, las cuales podían permanecer en el convento y al servicio de la casa de educación de esta ciudad ${ }^{84}$.

83 AGN, Sección República, Fondo Ministerio de Instrucción Pública, t. 123, ff. 87r-88r; t. 134, f. 109v.

84 AGN, Sección República, Fondo Negocios Eclesiásticos, t. 5, ff. 252r, 260r, 420r; Enrique BáEZ (fray), La Orden Dominicana en Colombia, Paipa, 1950, t. XVII, pp. 417-431. 


\section{REFLEXIONES FINALES}

Era evidente que, durante el fragor de las guerras de Independencia y el ascenso del gobierno republicano, el estamento eclesiástico había experimentado una situación de debilitamiento, confusión y divisiones internas, lo cual hacía parte del proceso de reacomodamiento a las nuevas circunstancias políticas y sociales. Si bien había perdido influencia en las élites, todavía seguía proyectando su gran poder sobre la sociedad.

No hay duda que desde los inicios del periodo republicano la Iglesia había expresado su apoyo al proyecto educativo planteado por el gobierno y eso quedó comprobado en su contribución al plan de implementación de escuelas y colegios públicos. No obstante, por otro lado empezó a observarse cierta hostilidad clerical frente a algunas decisiones gubernamentales que afectaban directamente sus intereses, como fue el caso de la orden de supresión de conventos, lo cual hizo que su posición de moderación asumida inicialmente se transformara en descontento creciente que sería uno de los factores que desencadenaron la crisis política que generó la disolución de la Gran Colombia ${ }^{85}$.

Entre tanto, el gobierno republicano buscaba consolidar su legitimidad y erigirse como máxima autoridad, lo cual implicaba avanzar progresivamente hacia el camino de la secularización. El Estado, aún ávido de legitimidad, con rentas exiguas y un incipiente aparato administrativo, vio la necesidad estratégica de controlar el poder político derivado de la gran influencia social y moral de la Iglesia ${ }^{86}$. Para ello, la tendencia liberal que prevalecía en el gobierno nacional abogaba por un regreso al cristianismo primitivo, contexto dentro del cual se criticaba el poder material alcanzado por el estamento eclesiástico ${ }^{87}$. La supresión de conventos y la destinación de las alhajas para la educación pública se enmarcan precisamente en ese propósito.

Vacíos en la ley, vacilación en las decisiones, falta de coherencia en las políticas oficiales y escasa coordinación entre los diferentes niveles de gobierno, fueron algunos de los factores que tornaron más compleja la disputa entre colegios y conventos por las alhajas en medio de un trasfondo de crisis económica generalizada y debilidad institucional.

Esta problemática permitió palpar el juego de poderes entre cada uno de los actores involucrados. Frailes, párrocos, funcionarios, rectores, maestros, estudian-

\footnotetext{
85 David Bushnell, El Régimen de Santander..., op. cit., p. 237.

86 Ibid., p. 223.

87 Fernán GonZáLeZ, Poderes enfrentados. Iglesia y Estado en Colombia, Bogotá, 1997, pp. 140-141.
} 
tes y comunidades se vieron envueltos en este choque de intereses, dinámica que ocurrió en medio de una etapa de transición en la que se estaba fraguando un reacomodamiento de fuerzas y un cambio en las prioridades de una nación en ciernes.

En la provincia del Socorro, la disputa en torno a las alhajas disponibles en el convento de San Francisco y en el convento de los capuchinos adquirió más un tinte político por cuanto se dio en medio de un trasfondo de continuas controversias jurisdiccionales a escala provincial y de una lucha de poderes entre autoridades locales y entre poblaciones. Quedaba en evidencia cómo la instalación de colegios era percibida, dentro del marco del nuevo régimen republicano, como una oportunidad para que la ciudad beneficiada alcanzara un mayor posicionamiento y prestigio dentro de la escala político-administrativa, además de ser vista como una fórmula efectiva para apalancar el progreso a nivel regional. Todo esto bajo la premisa de que la educación era la base y fundamento del gobierno representativo y una de las ventajas que les permitiría a los ciudadanos consolidar su libertad y sus derechos ciudadanos.

La reivindicación planteada por los habitantes de Vélez y Socorro frente a las tempranas pretensiones del colegio de San José de Guanentá se sustentaba en el derecho que alegaban tener sobre el usufructo de las alhajas para beneficio del desarrollo educativo local bajo el hecho simbólico de que sus conventos servirían de sede para las nacientes instituciones educativas.

En la provincia de Tunja, territorio marcado por una mayor tradición religiosa, se observó de una manera más acentuada el poder y capacidad de reacción de los conventos que no cesaban de aducir sus servicios prestados en favor de la causa de la Independencia. Particularmente, los conflictos suscitados en torno a la Virgen del Topo y al cuadro del Santo Ecce-homo permiten evidenciar las reivindicaciones de la comunidad en torno a la defensa de sus elementos sagrados, a los cuales habían rendido devoción a través de varias generaciones, lo cual fue un claro indicio de la persistente influencia del clero y de las creencias religiosas en la sociedad ${ }^{88}$. Esta influencia pudo ser mucho más pronunciada en los sectores populares en donde todavía no alcanzaban a llegar con fuerza los reducidos índices de cobertura en educación secundaria y en donde aún se necesitaban muchos más esfuerzos oficiales para entronizar el discurso liberal pregonado por el gobierno republicano.

Es por ello que las protestas de los feligreses fueron un elemento constante de preocupación para los dirigentes republicanos que, después de la larga zozobra

88 Ana María BIDEGAIN, La expresión de corrientes en la Iglesia neogranadina ante el proceso de reformas borbónicas y la emancipación política (1750-1821), en Ana María BIDEGAIN, Historia del Cristianismo en Colombia. Corrientes y diversidad, Bogotá, 2004, p. 178. 
y polarización vivida durante el periodo de Independencia, intentaron por todos los medios evitar que estas expresiones de descontento terminaran desbordándose o que se convirtieran en un factor más grave de perturbación social. Una prueba fehaciente del triunfo del fervor religioso popular fue el hecho de que finalmente ninguna de las imágenes más veneradas pudo ser vendida ni destinada a la financiación de la educación pública.

En este juego de poderes, el clero secular no fue del todo ajeno y en últimas resultó beneficiado por cuanto algunos representantes de este sector de la Iglesia llegaron a ocupar el cargo de rectores, tal como sucedió en el colegio de Boyacá y en el colegio de San José de Guanentá, en cuya circunstancia no escatimaron esfuerzos con miras a conseguir las alhajas para el fomento de sus instituciones educativas. Tampoco hay que olvidar que algunos curas consiguieron a precios relativamente asequibles algunas alhajas e inmuebles de los extintos conventos para dotar sus parroquias mientras que otros enfocaron su interés en lograr la custodia y administración de imágenes que gozaban de amplia veneración, culto que pudo significarles buenos dividendos.

En todos los casos revisados, salta a la vista la persistencia de los rectores en su propósito de conseguir recursos que permitieran aliviar las penurias económicas que experimentaban los colegios públicos en sus inicios, afán que en algunas situaciones los llevó a cometer excesos y abusos de poder. Desde sus primeras actuaciones, estos funcionarios dejaron entrever el liderazgo, la influencia y el peso político que esos cargos administrativos tendrían dentro del orden político a nivel provincial.

A fin de cuentas, el dilema sobre los mecanismos para disponer de las alhajas para el fomento de la educación pública era en realidad parte de una problemática administrativa y fiscal de mayores proporciones pues, con ello, solo se ofrecía un paliativo frente a un asunto que requería de soluciones estructurales y alternativas de fondo para asegurar la financiación y sostenibilidad de los colegios a largo plazo.

En últimas, este tipo de conflictos alusivos al incierto destino de las alhajas de los conventos suprimidos, enmarcado en las complejas relaciones entre el Estado y el estamento eclesiástico, sería apenas la primera expresión de una aguda polarización ideológica en torno al grado de influencia de la religión en la sociedad colombiana, disputas que se manifestarían de una manera más acentuada en las luchas partidistas y en las guerras civiles que asolaron al país a lo largo del siglo $\mathrm{XIX}^{89}$.

89 Fernán GonZÁLEZ, Iglesia y Estado en Colombia..., pp. 3-17. 
